\title{
ASYMMETRIC PULMONARY EDEMA AFTER SCORPION STING: A CASE REPORT
}

\author{
Ebrahim RAZI(1) \& Elaheh MALEKANRAD(2)
}

\begin{abstract}
SUMMARY
A 12-year-old boy was referred with acute asymmetric pulmonary edema (APE) four-hour after scorpion sting to Emergency department. On admission, the main clinical manifestations were: dyspnea, tachypnea, and tachycardia. Chest X-ray revealed APE predominantly on the right hemithorax. The patient was treated with oxygen, intravenous frusemide and digoxin and discharged on the sixth hospital day in a good condition. This case report emphasizes the occurrence of asymmetric pulmonary edema after severe scorpion envenomation within few hours immediately after the sting.
\end{abstract}

KEYWORDS: Asymmetric pulmonary edema; Scorpion; Sting.

\section{INTRODUCTION}

Scorpion stings are a common occurrence in $\operatorname{Iran}^{34}$. Most of the stings are harmless and follow a benign clinical course, but some present with serious and acute life-threatening complication in respiratory, neurologic and cardiovascular systems. The leading causes of death related to scorpion envenomation are cardiac dysfunction and pulmonary edema $^{16}$. Acute pulmonary edema due to scorpion sting is common but asymmetric and unilateral pulmonary edema is extremely rare with only few numbers of reported cases $^{3,14,15,22}$. We report a patient who developed radiographically documented APE predominantly on the right after a scorpion envenomation.

\section{CASE REPORT}

A previously healthy 12-year-old boy presented to the Emergency department of Kashan Shahid Beheshti Hospital four hours after being stung at the first toe of his right foot by a yellow scorpion (Odontobuthus doriae). He was stung during work at a brick-making factory in a rural area. The patient complained of severe local pain and swelling at the site of the bite. One hour after the sting, five vials of polyvalent scorpion antivenom (Razi Vaccine \& Serum Research Institute, Hesarak, Karaj, Iran) and tetanus toxin were administered parentally before he was referred to this Hospital. On examination, he was noted to be pale, disoriented and severely dyspenic. Findings on clinical examinations were as follows: pulse rate was $150 / \mathrm{min}$, and regular; blood pressure was $120 / 80 \mathrm{mmHg}$, respiratory rate $60 / \mathrm{min}$ and temperature $37.4^{\circ} \mathrm{C}$.

Examination of the respiratory system disclosed diminished breath sound throughout the right side of the chest, and crackles were heard at the base of the left lung. Cardiovascular system examination revealed S3 gallop at the apex. On the examination of the first toe of his right foot, the effect of sting as local pain, erythema and mild edema was present.

An electrocardiogram taken on admission showed sinus tachycardia at a rate of $140 / \mathrm{min}$.

Laboratory investigations showed: the sodium level of $136 \mathrm{mEq} / \mathrm{L}$, potassium $3.7 \mathrm{mEq} / \mathrm{L}$. The urinalysis was normal. Calcium level was $7.9 \mathrm{mg} / \mathrm{dL}$, BUN $20 \mathrm{mg} / \mathrm{dL}$, serum creatinine level was $1.3 \mathrm{mg} / \mathrm{dL}$. Erythrocyte sedimentation rate was $10 \mathrm{~mm} / \mathrm{h}$. White blood-cell count was $9300 / \mathrm{mm}^{3}$, with $85 \%$ neutrophils and $15 \%$ lymphocytes, the hematocrit was 32.5 percent, hemoglobin was $11.2 \mathrm{~g} / \mathrm{dL}$, and platelet count was $264000 / \mathrm{mL}$. Arterial blood gases while he was breathing room air showed arterial oxygen tension $(\mathrm{PaO} 2) 46 \mathrm{mmHg}$, partial carbon dioxide pressure (PaCO2) $29 \mathrm{mmHg}, \mathrm{HCO} 3=17 \mathrm{mEq} / \mathrm{L}$ and $\mathrm{pH} 7.40$.

The chest radiograph showed diffuse, fluffy, bilateral infiltrates, which were predominantly on the right side of hemithorax (Fig. 1) diagnosed as APE due to scorpion venom.

The patient was treated with oxygen, intravenous frusemide and digoxin. On the third hospital day, a chest radiograph showed improvement in the air-space opacifications (Fig. 2). The patient continued to improve, and he was discharged on the sixth hospital day in stable condition. At this time, chest x-ray showed marked improvement of lung edema (Fig. 3).

\section{DISCUSSION}

Scorpion stings are a major public health problem in many tropical countries. Out of 1500 scorpion species, 50 are dangerous to humans. Scorpion stings cause a wide range of manifestations, from several local skin reactions to neurologic, respiratory, and cardiovascular collapse. 


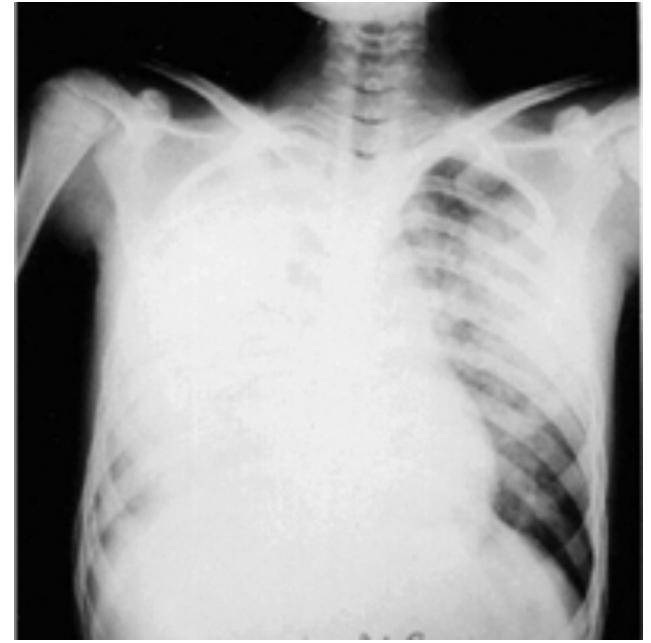

Fig. 1- Chest x-ray taken four hours after Odontobuthus doriae sting showing diffuse, fluffy, bilateral infiltrates, which are predominantly in the right hemithorax.

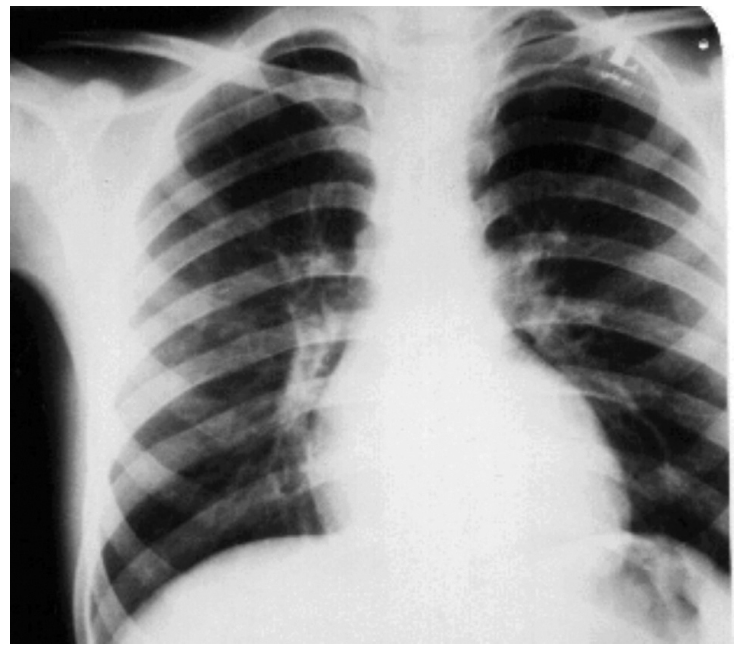

Fig. 2 - Chest x-ray taken two days later showing improvement of pulmonary edema.

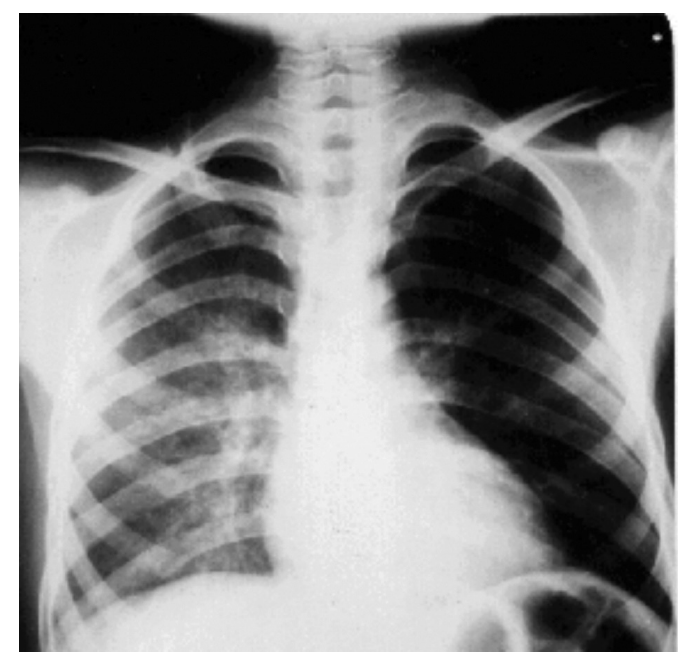

Fig. 3 - Chest $x$-ray taken at discharge from the hospital six days after the sting revealing significant improvement of asymmetric pulmonary edema.
Scorpion venom contains neurotoxin, hemolysins, agglutinins, haemorragins, leucocytolysins, coagulins, ferments, lecithin and chlolesterin ${ }^{30}$. In Iran most victims of scorpion sting are reported from Khozestan provinence in southwest of the country. Of the six known scorpion families, only the species of two families, i.e. Buthidae and Scorpionidae, occur in Iran. Hemiscorpius (Hemiscorpion) lepturus (HL), a species of the Scorpionidae, is found only in the southern most parts of Iran $^{35}$. From April 1990 to July 1996, 36,463 scorpion stings were referred to the scorpion sting clinic at Abuzar Hospital, Ahwaz, Iran, and a mean of 5610 per year with 61 deaths reported ${ }^{34}$. Recently, PIPELZADEH et al., reported that HL was responsible for $89 \%$ of the deaths and $92 \%$ of hospitalized scorpion-stung patients from the same region $^{31}$. In another study from Kashan, a city in central of Iran by DEHGHANI et al., reported that $30 \%$ of the cases were stung by the black scorpion Androctonus crassicauda, $62 \%$ by the yellow scorpions Mesobothus eupeus and livierus caucasicus and $8 \%$ were stung by unidentified species of scorpions ${ }^{12}$. As with other countries in the Middle East, Iran has several species of the most venomous scorpions that cause medical problems. Among the most dangerous scorpions of Iran are those that belong to the family Buthidae, such as Odontobuthus and Buthus. The genus Odontobuthus has three species: bidentatus, doriae and odonturus ${ }^{24,25}$. Specifically, Odontobuthus doriae, the yellow scorpion described in this study, can be found in central and southern parts of Iran (Fig. 4).

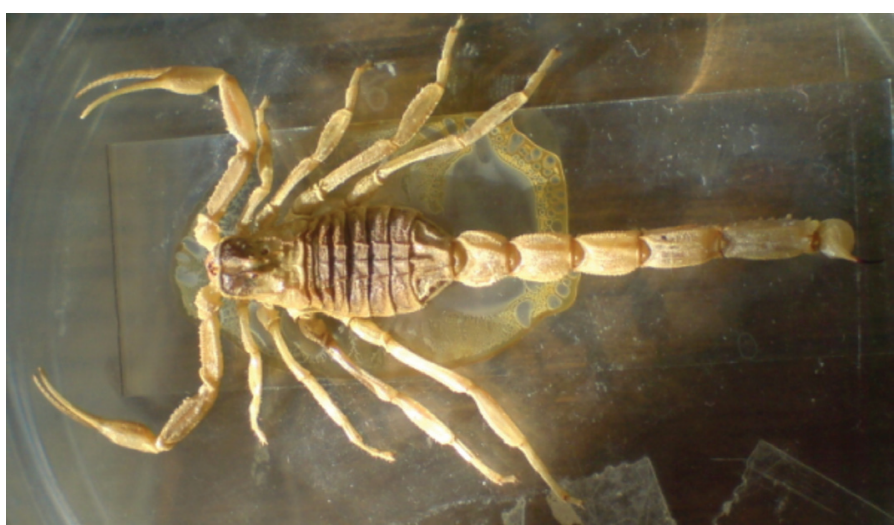

Fig. 4 - Odontobuthus doriae. This species is a pale, clear yellow color scorpion, easily recognized by the very dentate structures on the ventral size of the tail.

Regarding the epidemiological aspects of scorpionism, the majority of studied cases in Iran, were children aged less than 12 years old ${ }^{31}$. In the neighboring country, Turkey, $54.1 \%$ of the patients were adolescents ${ }^{1}$. In a total of 995 cases of poisoning in children that was conducted by GUPTA et al., from India, scorpion envenomations were reported in six subjects $0.6 \%{ }^{17}$. In another study, that was performed in relation to the epidemiology of acute childhood poisoning, BASU et al., from India revealed that $3.6 \%$ of total pediatric admissions were due to poisoning ${ }^{4}$. Majority of the cases included oral/chemical poisoning followed biological/envenomation ${ }^{4}$. In a study HEMMO-LOTEM et al., in Israel over a 1-year period reported that, $2.1 \%$ of all pediatric trauma cases treated in the emergency department were bite/sting injuries ${ }^{18}$. Children with scorpion or hornet stings and young age were more likely to be hospitalized ${ }^{18}$.

The toxicity and clinical picture are related to species differences and venom dose/weight relationship. Case fatalities of 3-22\% were reported 
among children hospitalized for scorpion stings in India, Saudi Arabia and South Africa ${ }^{7,13,25,27,35}$. Symptoms after scorpion sting progress to a maximal severity in about five hours and subside within a day or two. In USA, clinical progression following scorpion envenomation in children $<$ or $=2$ y old occurred on average within 14 min of envenomation with onset almost immediately ${ }^{26}$. Centruroides sculpturatus, also known as Centruroides exilicauda or bark scorpion, is the only scorpion native to the United States whose venom produces a potentially life-threatening illness, particularly in children ${ }^{26}$.

Scorpion venom is a powerful stimulant of the autonomic nervous system. The primary action of the venom is through both sympathetic and parasympathetic postganglionic stimulation. In most circumstances, the sympathetic response predominates, resulting in what has been described as a "sympathetic storm" 37 . Arterial hypertension, tachycardia, myocardial dysfunction, pulmonary edema and cool extremities have been attributed to stimulation of alpha-receptors by the scorpion toxins ${ }^{5}$. A direct stimulant action on the heart has also been proposed ${ }^{19}$. In regard to mechanism of scorpion venom in pathogenesis of respiratory failure and pulmonary edema, COMELLAS et al., concluded that it decreases clearance of alveolar fluid probably secondary to downregulation of sodium, potassium-ATPase in the alveolar epithelium ${ }^{10}$.

CUPO et al., recently reported that, the mechanism of the acute cardiac dysfunction caused by severe scorpion envenoming is related to transitory myocardial ischemia ${ }^{11}$. In these patients micro vascular spasm may lead to catecholamine over stimulation and consequently disturbance of myocardial perfusion. JALALI et al., reported that the main facilitatory effects of Odontobuthus doriae venom are likely to be due to toxins that affect $\mathrm{Na}(+)$ channels in nerve-muscle preparations similar to most Old World scorpion venoms, but blocking effects on $\mathrm{K}$ (+) channels are also possible ${ }^{20}$. Scorpion venom might cause myocardial damage and cardiac depression directly or by one or more circulatory myocardial depressant substances.

It has been suggested that these circulating myocardial depressant substances have biochemical and pathogenic characteristics similar to those of a number of cytokines and particularly tumor necrosis factor ${ }^{9}$. Tumor necrosis factor (TNF) could be involved in the cardiovascular effects caused by scorpion venom ${ }^{23}$. Pulmonary edema may develop within 30 minutes to three hours after a sting due to myocardial dysfunction. Development of symptoms associated with pulmonary edema is variable but may be rapid. Tachypnea or intractable cough on admission could be signs of pulmonary evolving edema. In scorpion envenomation patients older than three years, the association of a respiratory rate of $>$ or $=30$ breaths/minute, agitation, sweating, or the presence of high plasma protein concentrations suggest the presence of pulmonary edema ${ }^{8}$.

Close monitoring is indeed vital to detect and treat pulmonary edema. Children appear pale with clammy skin and have tachycardia with elevated blood pressure, rib retractions, nasal flaring and grunting. Pink frothy sputum as classically described in adults is not always present in children. Some children relapse into acute pulmonary edema while showing apparent signs of recovery. Reported deaths within 30 minutes in some of these children are due to ventricular arrhythmias. Non-cardiac mechanisms have also been proposed to explain pulmonary edema due after Tityus serrulatus scorpion stings ${ }^{2}$. In majority of children changes in chest $X$-ray suggestive of pulmonary edema are seen even within three hours after sting. These children are not tachypneic surprisingly, though some of them become symptomatic in the next six hours.

Our patient responded dramatically to treatment with oxygen, digitalis and diuretics. In a study that was reported by BHADANI et al., from Nepal on patients with pulmonary edema due to scorpion sting envenomation, all of them were successfully managed with the positive end-expiratory pressure (PEEP), cardiac support with inotropes and fluid balance $^{6}$. The results of oral captopril in treatment of scorpion induced cardiovascular manifestations have also been reported safe ${ }^{21}$.

Asymmetric and unilateral pulmonary edema, though well documented in the medical literature, is an uncommon entity. It mostly affects patients with cardiac failure who are in a dependent position $^{28}$. Pulmonary edema due to scorpion envenomation is well known but its unilateral occurrence is rare $^{3,14,15,22}$. The mechanism of acute pulmonary edema induced by scorpion venom, however, is not completely understood ${ }^{32}$. Many factors may be implicated in its genesis. Cardiogenic and non-cardiogenic factors are involved in the pathogenesis of pulmonary edema following scorpion sting. AMARAL et al., reported predominantly unilateral pulmonary edema ${ }^{3}$. Unilateral pulmonary edema secondary to left-sided heart failure seldom occurs in the absence of previous lung injury. This may be explained by a simultaneous and localized increase in pulmonary vascular permeability induced by scorpion venom. The patchy and peripheral distribution of lung edema indicates increased vascular permeability. In study of MAZZEI DE DAVILA et al., that was carried out in patients with cardiovascular manifestations of pulmonary edema induced by scorpion envenomation, plasma norepinephrine was elevated in seven of eight patients ${ }^{29}$. Patients have variable degrees of pulmonary edema. FREIRE-MAIA et al., reported several cases of unilateral pulmonary edema in a cohort study that involved 3866 patients stung by Tityus serrulatus scorpion ${ }^{15}$. KULKARNI et al., reported unilateral pulmonary edema in a 28 -year old patient who presented with manifestations of acute left ventricular failure following scorpion sting $^{22}$. In another study SANTANA et al., reported that after subcutaneous injection of Tityus serrulatus scorpion venom, unilateral pulmonary edema was induced in three of six rats ${ }^{36}$.

Recently EL-FORTIA et al., reported a case of scorpion-sting induced unilateral pulmonary edema in a 55-year-old male from Libya ${ }^{14}$.

In conclusion, this case report emphasizes the occurrence of asymmetric pulmonary edema after scorpion envenomation. Pulmonary edema was suspected clinically and further documented on chest X-ray and was treated with oxygen, digitalis and diuretics.

\section{RESUMO}

\section{Edema pulmonar assimétrico após picada de escorpião: relato de caso}

Menino de 12 anos foi internado no Pronto Socorro, com edema pulmonar assimétrico agudo (APE), quatro horas após picada de escorpião. À admissão, as principais manifestações clínicas foram: dispnéa, taquipnéa e taquicardia. Raio X do pulmão revelou APE predominantemente no hemitórax direito. $\mathrm{O}$ paciente foi tratado com oxigênio, frusemida intravenosa e digoxina e teve alta no sexto dia de internação, em boas condições. Este relato de caso enfatiza a ocorrência de edema pulmonar assimétrico algumas horas após a picada. 


\section{REFERENCES}

1. ADIGUZEL, S.; OZKAN, O. \& INCEOGLU, B. -. Epidemiological and clinical characteristics of scorpionism in children in Sanliurfa, Turkey. Toxicon, 49: 875-880, 2007.

2. AMARAL, C.F.; REZENDE, N.A. \& FREIRE-MAIA, L. - Acute pulmonary edema after Tityus serrulatus scorpion sting in children. Amer. J. Cardiol., 71: 242-245, 1993.

3. AMARAL, C.F. \& REZENDE, N.A. - Both cardiogenic and non-cardiogenic factors are involved in the pathogenesis of pulmonary oedema after scorpion envenoming. Toxicon, 35: 997-998, 1997.

4. BASU, K.; MONDAL, R.K. \& BANERJEE, D.P. -Epidemiological aspects of acute childhood poisoning among patients attending a hospital at Kolkata. Indian J. publ. Hlth, 49: 25-26, 2005.

5. BAWASKAR, H.S. \& BAWASKAR, P.H. - Management of cardiovascular manifestations of poisoning by the Indian red scorpion (Mesobuthus tamulus). Brit. Heart J., 68: 478-480, 1992

6. BHADANI, U.K.; TRIPATHI, M.; SHARMA S. \& PANDEY, R. - Scorpion sting envenomation presenting with pulmonary edema in adults: a report of seven cases from Nepal. Indian J. med. Sci., 60: 19-23, 2006.

7. BISWAL, N.; MURMU. U.C.; NALINI, P. et al. -Management of scorpion envenomation. Pediat. today, 2: 420-426, 1999.

8. BOUAZIZ, M.; BAHLOUL, M.; HERGAFI, L. et al. - Factors associated with pulmonary edema in severe scorpion sting patients: a multivariate analysis of 428 cases. Clin. Toxicol. (Phila.), 44: 293-300, 2006.

9. CARLi, A.; AUCLAIR, M.C.; BENASSAYAG, C. \& NUNEZ, E. - Evidence for an early lipid soluble cardiodepressant factor in rat serum after a sublethal dose of endotoxin. Circ. Shock, 8: 301-312, 1981.

10. COMELlAS, A.P.; PESCE, L.M.; AZZAM, Z.; SALDÍAS, F.J. \& SZANJDER, J.I. - Scorpion venom decreases lung liquid clearance in rats. Amer. J. respir. crit. Care Med., 167: 1064-1067, 2003

11. CUPO, P.; FIGUEIREDO, A.B.; FILHO, A.P. et al. - Acute left ventricular dysfunction of severe scorpion envenomation is related to myocardial perfusion disturbance. Int. J. Cardiol., 116: 98-106, 2007.

12. DEHGHANI, R.; DOROUDGAR, A.; KHADEMI, M.R. \& SAYYAH, M. - The survey of scorpion sting in the city of Kashan. J. Res. Med. Sci., 3: 132-135, 1998.

13. DUDIN, A.A.; RAMBAUD-COUSSON, A.; THALJI, A.; JUABEH, I.I. \& ABULIBDEH, B. - Scorpion sting in children in Jerusalem area: a review of 54 cases. Ann. trop. Pediat., 11: 217-223, 1991

14. EL-FORTIA, M.; EL-GATIT, A.; ELMAGBERI, F. \& BENDAOUD, M. - Scorpionsting induced unilateral pulmonary edema. Europ. J. Radiol. Extra, 53: 21-23, 2005 .

15. FREIRE-MAIA, L.; CAMPOS, J.A. \& AMARAL, C.F. - Approaches to the treatment of scorpion envenoming. Toxicon, 32: 1009-1014, 1994.

16. GUERON, M.; ILIA, R. \& SOFER, S. - The cardiovascular system after scorpion envenomation: a review. J. Toxicol. clin. Toxicol., 30: 245-258, 1992.

17. GUPTA, S.K.; PESHIN, S.S.; SRIVASTAVA, A. \& KALEEKAL, T. - A study of childhood poisoning at National Poisons Information Centre, All India Institute of Medical Sciences, New Delhi. J. occup. Hlth, 45: 191-196, 2003.

18. HEMMO-LOTEM, M.; BARNEA, Y.; JINICH-ARONOWIZ, C. et al. - Epidemiology of pediatric bite/sting injuries. One-year study of a pediatric emergency department in Israel. Scient. Wld J., 6: 653-660, 2006.
19. ISMAIL, M.; OSMAN, O.H.; IBRAHIM, S.A. \& EL-ASMAR, M.F. - Cardiovascular and respiratory response to the venom from the scorpion Leiurus quinquestriatus. East Afr. med. J., 49: 274-281, 1972.

20. JALALI, A.; VATANPOUR, H.; HOSSEININASAB, Z.; ROWAN, E.G. \& HARVEY, A.L. - The effect of the venom of the yellow Iranian scorpion Odontobuthus doriae on skeletal muscle preparations in vitro. Toxicon, 50: 1019-1026, 2007.

21. KRISHNAN, A.; SONAWANE, R.V. \& KARNAD, D.R. - Captopril in the treatment of cardiovascular manifestations of Indian red scorpion (Mesobuthus tamulus concanesis Pocock) envenomation. J. Ass. Phycns India, 55: 22-26, 2007.

22. KULKARNI, H.K.; BRID, N.S. \& KULKARNI, A.G. - Unilateral pulmonary oedema following scorpion sting: a case report. Lung India, 13: 17-19, 1995.

23. KUMAR, A.; DIMOU, C. \& HOLLENBERG, S.M. - Tumor necrosis factor produces a concentration-dependent depression of myocardial cell contraction in vitro Clin. Res., 39: 321A, 1991.

24. LATIFI, M. \& TABATABAI, M. - Immunological studies on Iranian scorpion venom and antiserum. Toxicon, 17: 617-621, 1979.

25. LOURENCO, W.R. \& PEZIER, A. - Taxonomic consideration of the genus Odontobuthus Vachon (Scorpiones, Buthidae), with description of a new species. Rev. Suisse Zool., 109: 115-125, 2002

26. LoVECCHIO, F. \& McBRIDE, C. - Scorpion envenomations in young children in central Arizona. J. Toxicol. clin. Toxicol., 41: 937-940, 2003.

27. MAHADEVEN, S.; CHOUDHURY, P.; PURI, R.K.; \& SRINIVASAN, S. - Scorpion envenomation and the role of lytic cocktail in its management. Indian J. Pediat., 48: $757-761,1981$

28. MAHFOOD, S.; HIX, W.R.; AARON, B.L.; BLAES, P. \& WATSON, D.C. Reexpansion pulmonary edema. Ann. Thorac. Surg., 45: 340-345, 1988.

29. MAZZEI DE DAVILA, C.A.; DAVILA, D.F.; DONIS, J.H. et al. -Sympathetic nervous system activation, antivenin administration and cardiovascular manifestations of scorpion envenomation. Toxicon, 40: 1339-1346, 2002.

30. MODI, N.J. - Modi's textbook of medical Jurisprudence and Toxicology. 24. ed. Bombay, N.M. Tripathi, 1977. p. 633.

31. PIPELZADEH, M.H.; JALALI, A.; TARAZ, M. et al. - An epidemiological and a clinical study on scorpionism by the Iranian scorpion Hemiscorpius lepturus. Toxicon, 50: 984-992, 2007.

32. RADHA KRISHNA MURTHY, K. - The scorpion-envenoming syndrome: a different perspective. The physiological basis of the role of insulin in scorpion envenoming. J. venom. Anim. Toxins, 6: 4-51, 2000.

33. RADMANESH, M. - Clinical study of Hemiscorpion lepturus in Iran. J. trop. Med. Hyg., 93: 327-332, 1990.

34. RADMANESH, M. - Cutaneous manifestations of the Hemiscorpius lepturus sting: a clinical study. Int. J. Derm., 37: 500-507, 1998.

35. RAJARAJESWARI, G.; SIVAPRAKASAM, S. \& VISWANATHAN, J. - Morbidity and mortality pattern in scorpion sting: a review of 68 cases. J. Indian med. Ass., 73: $123-126,1979$

36. SANTANA, G.C.; FREIRE, A.C.; FERREIRA, A.P. et al. - Pharmacokinetics of Tityus serrulatus scorpion venom determined by enzyme-linked immunosorbent assay in the rat. Toxicon, 34: 1063-1066, 1996.

37. YAROM, R. - Scorpion venom: a tutorial review of its effects in men and experimental animals. Clin. Toxicol., 3: 561-569, 1970.

Received: 18 May 2007

Accepted: 24 September 2008 